\title{
An Evaluation of Selected Economic Areas according to Similarity of Supply and Demand Shocks ${ }^{1}$
}

\section{Stanislav Kappel ${ }^{2}$}

\begin{abstract}
The Euro Area remains a well-known monetary union in the World. But the possibilities of creation of new monetary unions are discussed. It is spoken about NAFTA (Canada, Mexico and the United States) or MERCOSUR (Argentina, Brazil, Paraguay, Uruguay and Venezuela). The aim of this paper is to assess the similarity of demand and supply shocks in the countries of NAFTA and MERCOSUR, and to compare it with the countries of the Euro Area. For these aims, correlation and structural vector autoregression methods are used. Methods are based on Blanchard and Quah (1989) and Bayoumi and Eichengreen (1993). We confirm the existence of core states and periphery states in the Euro Area with some exceptions. If we compare supply and demand shocks, we find more similarity in the case of supply shocks in the countries of the Euro Area. According to the results, the countries of NAFTA are more appropriate for the creation of monetary union than the countries of MERCOSUR. The countries of NAFTA achieve high correlation coefficients of supply and demand shocks (except Mexico for supply shocks).
\end{abstract}

Key words: OCA theory, supply and demand shocks, the Euro Area, NAFTA, MERCOSUR

JEL Classification: C32, E32, E37

\section{Introduction}

The Euro Area is a well-known monetary union in the World. But there are some economic areas which are important and their influence is still arising. It is especially the NAFTA (the North American Free Trade Agreement) in North America and MERCOSUR (Common Market of the South) in South America. These two economic areas, a free trade area in the case of NAFTA and a customs union in the case of MERCOSUR, are sometimes discussed in connection with a creation of a monetary union.

Monetary unions and their research are one of the parts of monetary theory. Creation of a monetary union is a very high degree of an economic integration among states. The member state gives up its independent monetary policy in the case of entry to a monetary union. Membership in a monetary union has many advantages, particularly

\footnotetext{
${ }^{1}$ The paper was made thanks to the project SGS VŠB-TUO SP2014/115 "Assessing the Macroeconomic Impacts of Uncovential Monetary Policy Measures of Selected Central Banks“.

${ }^{2}$ VŠB - Technical University of Ostrava, Department of Economic Policy, Faculty of Economy, Sokolská tř́́da 33, 70121 Ostrava, Czech Republic. Email: stanislav.kappel@vsb.cz.
} 
reduction of transaction costs and elimination of exchange rate risks. On the other hand, it also has some disadvantages, of which loss of autonomy of monetary policy is the biggest.

The aim of this paper is to assess the similarity of demand and supply shocks in the countries of NAFTA and MERCOSUR and to compare it with the countries of the Euro Area. In order to reach this aim we examine correlation of supply and demand shocks among the countries of the Euro Area, NAFTA and MERCOSUR.

The question of asymmetric shock appeared already in Mundell (1961). Since the 1960s, new techniques of how to study and research supply and demand shocks have been developed. Similarities of supply and demands shocks of countries are one of the main empirical methods to quantify costs and benefits of membership with. Mongelli (2002) claims that if incidence of a demand and supply shock is similar across countries in a monetary union, then the benefit of a single currency is higher than the need for policy autonomy. Our model is based on methods of Blanchard and Quah (1989) and Bayoumi and Eichengreen (1993). We identify supply and demand shocks through their impact on output and a price level. We assume that demand shocks have only temporary impact on output, and the supply shock has a permanent impact on output. In addition, both have a permanent effect on a price level. These assumptions are based on the aggregate demand-aggregate supply model (AS-AD model).

The remainder of this paper is organized as follows: The next section deals with review of literature that focuses on the optimum currency area theory, similarity of supply and demand shocks and analysed areas. The part that follows it deals with methods and data. Results are introduced in the next section and finally, conclusion is offered in the last section.

\section{Theoretical and Empirical Literature}

\section{Optimum Currency Area Theory}

The research of the theory of optimum currency area (OCA) commenced in the 1960s. Mundell (1961) is regarded as a pioneer of the OCA theory. Mundell (1961) analyses a situation of an adaptation in the case of an asymmetric shock. He defines the optimum currency area as an area with external immobility and internal mobility of production factors (especially labour). According to Mundell (1961), a flexible exchange rate must exist among some countries (or areas) because the world is not an optimum currency area. In the case of an asymmetric shock, the adaptation with internal immobility of production factors can be reached only with a flexible exchange rate. McKinnon (1963) extends the theses of Mundell (1961), claiming that a degree of openness of economy is another condition for creation of a monetary union. He defines the openness as a proportion of tradable and non-tradable goods. A fixed exchange rate is more appropriate for open economy; on the other hand, flexible exchange rate is what is more appropriate for closed economy. The third well-known paper, written by Kenen (1969), appeared in the 1960s, too. Kenen here adds a third criterion: Diversification in production and consumption. According to Kenen (1969), a flexible exchange rate is better for economy with diversification of production and consumption, whilst a fixed exchange rate is more appropriate for economy with less diversification of production and consumption. 
In economy with diversification of production and consumption there are not changes in terms of trade in the case of asymmetric shock.

During the time, other criteria have been added (Mongelli, 2002; Lacina et al, 2007 or de Grauwe, 2014): Financial market integration, similarities of inflation rates, fiscal integration, price and wage similarities, political integration, similarities of supply and demand shocks or business cycles synchronization.

As mentioned above, reactions of economies in the case of asymmetric shock were researched already in Mundell (1961). One of the macroeconomic approach of the optimum currency area theory deals with analysing of economic shocks and their symmetry or asymmetry (Kučerová, 2005). In the case of asymmetric shock and lower alignment of business cycle, it is more appropriate for an economy to keep its own, autonomy monetary policy. There are two economic approaches for business cycle in the OCA theory. The first approach is based on theory of specialization, represented especially by Krugman (1993) who argues that business cycles are idiosyncratic after entering into a monetary union. Countries begin to specialize after they have entered a monetary union due to comparative advantages and reduction of transaction costs. It tends to divergence of business cycles. The second approach is represented by e.g. Frankel and Rose (1996), who claim that alignment of business cycles depends on their bilateral trade. If two countries have higher mutual trade, it will tend to a higher alignment of business cycles.

\section{Supply and Demand Shocks}

For identifying of supply and demand shocks, Blanchard and Quah (1989) use a structural vector autoregression (VAR) model. Gross national product (GNP) and rate of unemployment are variables used for identifying supply and demand shocks. They use data from 1950 to 1978 in the United States. Bayoumi and Eichengreen (1993) modify their approach in such a way that they use the variable price level instead of the variable rate of unemployment, and estimate a structural VAR model with differences of logarithms of GDP and the price level. They use data from 1960 to 1988 and compare supply and demand shocks among 11 EC countries (European Community) and the United States (US) regions. They claim that US regions are more similar in the case of supply and demand shocks.

Using quarterly data from 1991 to 2000, Fidrmuc and Korhonen (2003) compare the Central and Eastern European countries and countries of the Euro Area. They state that similarity of demand and supply shocks is lower in countries which joined the European Union later and in some countries of the so-called periphery of the Euro Area, too. Frenkel and Nickel (2002) also analyse demand and supply shocks between the Central and Eastern European countries and the Euro Area countries from the first quarter 1993 to the first quarter 2001 and find differences in shocks between the Central and Eastern European countries and the Euro Area. Horvath and Rátfai (2004) examine the shocks in five Visegrad (the Czech Republic, Slovakia, Hungary, Poland and Slovenia) and three Baltic (Estonia, Latvia and Lithuania) countries which they compare to the core countries of the Euro Area (they mean Germany, France and Italy). Their comparison uses the data from the first quarter of 1993 to the third quarter of 2000. These authors find a high degree of correlation of supply and demand shocks among the Visegrad and 
Baltic countries, but a low degree of correlation of shock in relation to Germany, France and Italy.

Hušek and Formánek (2011) focus their research on the Czech Republic. They compare supply and demand shocks in the Czech Republic with selected countries (Austria, Germany, Spain, France, Greece, Poland, Slovakia and the Euro Area). They use quarterly data from 2002 to 2010. Hušek and Formánek (2011) find persistent differences in symmetry of economic shocks in the Czech Republic with the Euro Area researched countries. Krčílková and Zápal (2012) examine similarities of demand and supply shocks in three sectors of economy - in agriculture, industry and services. Their research of countries of Central and Eastern Europe in relation to Germany and the Euro Area is based on quarterly data from 1995 to 2009. They conclude that similarity of demand and supply shocks in economic sectors are smaller than similarity in economy as a whole in the analysed countries.

Fidrmuc and Korhonen (2006) review the literature on supply and demand shocks and business cycle correlation between the Euro Area and the Central and Eastern European countries. They claim in their meta-analysis of thirty five publications that economic cycles in the Central and Eastern European countries are comparatively highly correlated to the Euro Area cycle.

\section{Analysed Areas}

The Euro Area was created in 1999. The origins come from the European Coal and Steel Community (ECSC) and the European Economic Community (EEC), formed in the 1950s. In 1986, the Single European Act was signed which sets the objective to establish a single market. European Union was formally established by the Maastricht Treaty in 1992, which came into force in 1993. European Monetary System, created in 1979, which consisted of Exchange Rate Mechanism (ERM), European Currency Unit (ECU) and credit mechanism, was the predecessor of Euro Area ${ }^{3}$. Currently, Euro Area has nineteen members: Austria (1999), Belgium (1999), Cyprus (2008), Estonia (2011), Finland (1999), Germany (1999), Greece (2001), Ireland (1999), Italy (1999), Latvia (2014), Lithuania (2015), Luxemburg (1999), Malta (2008), the Netherlands (1999), Portugal (1999), Slovakia (2009), Slovenia (2007) and Spain (1999) ${ }^{4}$.

The North American Free Trade Agreement (NAFTA) is the largest trade block in the world. It was established as a free trade area in 1994. It consists of Canada, Mexico and the United States. Chriszt (2000) argues that NAFTA is ready for creating a monetary union according to the OCA theory. He continues that Canada is more prepared than Mexico to join to the United States and he shows two basic approaches for creation of a monetary union among the states of NAFTA. Acceptance of the US dollar by Canada and Mexico, i.e. dollarization is the first possibility. The second possibility consists in creating a new common currency. The most frequent name as the name of the currency

\footnotetext{
${ }^{3}$ For more e.g. Lacina et al (2007) or Dědek (2008).

${ }^{4}$ Years of accession of the countries into the Euro Area are introduced in parentheses.
} 
is Amero. On the other hand, Cohen (2004) claims that for the United States, creation of NAMU (North American Monetary Union) would bear more costs than benefits.

MERCOSUR (Mercado Comúndel Sur; Common Market of the South) is a trade agreement among some states of the South America. This group was established as a customs union based on the agreement from Asuncion in 1991. Argentina, Brazil, Paraguay and Uruguay were the founding members, with Venezuela joining them in 2012. In the 1980s, Argentina and Brazil created a common program of integration and cooperation called PICE (Programa de Integração e Cooperação Econômica Argentina-Brasil; Programa de Integración y Cooperación Económica Argentina-Brasil). Numa (2011) claims that the program suggested common currency called "Gaucho". MERCOSUR was originally created as a free trade area but as the time progressed, it was transformed into a customs union in the 1990s and at the beginning of the new millenium. It began to function as a customs union in 2006 (Grigoli, 2012). Numa (2011) argues that MERCOSUR states are not ready for creation of a common currency at this time because the conditions for accepting common currency have not been fulfilled.

\section{Methods and Data}

\section{Methods}

As mentioned above, we use correlation and a structural vector autoregression. The structural vector autoregression model is based on Blanchard and Quah (1989) and Bayoumi and Eichengreen (1993). For identifying supply and demand shocks, Blanchard and Quah (1989) use a VAR model with variables gross national product and rate of unemployment. Bayoumi and Eichengreen (1993) estimate a structural VAR model with differences logarithms of GDP and the price level. Our access is similar and the model has the following specification:

$$
\left[\begin{array}{l}
\Delta y_{t} \\
\Delta p_{t}
\end{array}\right]=\sum_{j=0}^{\infty} L^{j}\left[\begin{array}{ll}
a_{11 i} & a_{12 i} \\
a_{21 i} & a_{22 i}
\end{array}\right]\left[\begin{array}{l}
\epsilon_{d t} \\
\epsilon_{s t}
\end{array}\right]
$$

where $y_{t}, p_{t} \quad$ represent the logarithms of output and prices,

$$
\begin{array}{ll}
a_{11 i} & \text { represents element } a_{11} \text { in matrix } A_{i}, \\
\epsilon_{d t}, \epsilon_{s t} & \text { are independent demand and supply shocks. }
\end{array}
$$

The idea is as follows: There are two types of shocks in an economy - demand shocks, and supply shocks. Firstly, we imply that supply shock has a permanent effect on output and that a demand shock has only temporary effect on output. Moreover, both have permanent effects on the price level.

Secondly, the model must have the restriction:

$$
\sum_{i=0}^{\infty} a_{11 i}=0
$$


Both demand and supply shocks are identified with the help of the restriction (equation 2 ). It means that the long-term impact of demand shocks on the output is zero.

In the model (1), four restrictions are required (Fidrmuc and Korhonen, 2003). First restriction is defined in the equation (2), the second one and the third one is the assumption that demand and supply shocks are orthogonal, and the last two restrictions are simply normalizations defining the variance of the shocks $\epsilon_{d t}$ and $\epsilon_{s t}$.

Hušek (2009) divides construction of VAR models into four phases. The first phase is intended to achieve stationary time series. In the second one, variables of the model and lags are chosen. The third phase is simplification of a model, and the last phase is orthogonality of residuals.

Data were statistically analysed, logarithmized and differentiated. In all cases, stationary time series of variables were confirmed according to ADF (Augmented Dickey-Fuller) test. The estimation of the number of VAR lags (sequential modified LR test statistic, Akaike information criterion, Schwarz information criterion and Hannan-Quinn information criterion ${ }^{5}$ ) are introduced in Appendix 1. The optimal lag was chosen primarily according to Akaike information criterion (AIC). However, due to stability of the model, other information criteria were taken into account in some cases, too.

\section{Data}

Data were obtained from the Eurostat database (Eurostat, 2014) for the Euro Area countries - Austria (AT), Belgium (BE), Cyprus (CY), Estonia (EE), Finland (FI), France (FR), Germany (DE), Greece (EL), Ireland (IE), Italy (IT), Latvia (LV), Lithuania (LT), Luxemburg (LU), Malta (MT), the Netherlands (NL), Portugal (PT), Slovenia (SI), Spain (ES) and Slovakia (SK), including the whole Euro Area (EA); for NAFTA countries - Canada (CAN), Mexico (MEX) and the United States (USA) from the OECD database (OECD, 2014); and for MERCOSUR countries - Argentina (ARG), Brazil (BRA), Paraguay (PAR), Uruguay (URY) and Venezuela (VEN), from the CEPALSTAT $^{6}$ database (CEPALSTAT, 2014). The analysed period is based on quarter observations from 1999 to 2013.

\section{Results}

Empirical results of similarity of demand and supply shocks are presented in this section, and are provided in the following order: Euro Area, NAFTA and MERCOSUR. Accumulated impulse-response functions of output of the researched states in Appendix 2 are introduced. We can see permanent effect of supply shock on output and temporary effect of demand shock on output.

\footnotetext{
${ }^{5}$ For more information on these criteria see Hušek (2009) or Lüthkepohl and Krätzig (2004).

${ }^{6}$ CEPALSTAT is a statistical database of the Economic Commission for Latin America and the Caribbean, United Nations.
} 


\section{The Euro Area countries}

For the countries of the Euro Area, results are introduced for similarity of demand shocks in the Table 1 and for similarity of supply shocks in the Table 2. The countries are introduced such an order in which they entered to the Euro Area (and in alphabetical order of abbreviations of countries in the case of original states of the Euro Area). The Euro Area as a whole is introduced as the last one.

Table 1 Similarity of demand shocks in the Euro Area

\begin{tabular}{|c|c|c|c|c|c|c|c|c|c|c|c|c|c|c|c|c|c|c|c|}
\hline & $\mathrm{AT}$ & $\mathrm{BE}$ & $\mathrm{DE}$ & ES & FI & FR & IE & IT & LU & NL & PT & EL & SI & $\mathrm{CY}$ & MT & SK & $\mathrm{EE}$ & LV & LT EA \\
\hline AT & 1 & & & & & & & & & & & & & & & & & & \\
\hline $\mathrm{BE}$ & 0.48 & 1 & & & & & & & & & & & & & & & & & \\
\hline $\mathrm{DE}$ & 0.15 & 0.40 & 1 & & & & & & & & & & & & & & & & \\
\hline ES & 0.12 & 0.21 & 0.37 & 1 & & & & & & & & & & & & & & & \\
\hline FI & 0.28 & 0.51 & 0.53 & 0.16 & 1 & & & & & & & & & & & & & & \\
\hline FR & 0.24 & 0.45 & 0.52 & 0.37 & 0.44 & 1 & & & & & & & & & & & & & \\
\hline IE & 0.18 & 0.26 & 0.25 & 0.04 & 0.13 & 0.22 & 1 & & & & & & & & & & & & \\
\hline IT & 0.04 & 0.39 & 0.40 & 0.22 & 0.38 & 0.46 & 0.07 & 1 & & & & & & & & & & & \\
\hline LU & 0.33 & 0.14 & 0.28 & 0.08 & 0.31 & 0.28 & 0.27 & 0.15 & 1 & & & & & & & & & & \\
\hline NL & 0.07 & 0.17 & 0.56 & 0.22 & 0.41 & 0.39 & 0.36 & 0.31 & 0.30 & 1 & & & & & & & & & \\
\hline PT & 0.11 & 0.25 & 0.43 & 0.11 & 0.36 & 0.23 & 0.32 & 0.16 & 0.48 & 0.24 & 1 & & & & & & & & \\
\hline EL & 0.06 & 0.10 & 0.10 & 0.11 & 0.08 & 0.24 & 0.23 & 0.08 & 0.14 & 0.20 & 0.09 & 1 & & & & & & & \\
\hline SI & 0.22 & 0.43 & 0.26 & 0.08 & 0.30 & 0.26 & 0.14 & 0.19 & 0.12 & 0.15 & 0.21 & 0.19 & 1 & & & & & & \\
\hline CY & 0.05 & 0.01 & 0.14 & 0.13 & 0.17 & 0.17 & 0.10 & 0.14 & 0.02 & 0.09 & 0.07 & 0.18 & 0.11 & 1 & & & & & \\
\hline MT & -0.11 & 0.06 & 0.19 & 0.01 & 0.17 & 0.24 & 0.01 & 0.04 & 0.001 & 0.22 & 0.24 & 0.24 & 0.23 & 0.21 & 1 & & & & \\
\hline SK & 0.06 & 0.36 & 0.27 & 0.24 & 0.40 & 0.27 & 0.18 & 0.16 & 0.13 & 0.24 & 0.23 & 0.11 & 0.45 & 0.32 & 0.26 & 1 & & & \\
\hline $\mathrm{EE}$ & 0.16 & 0.32 & 0.35 & 0.37 & 0.32 & 0.22 & 0.003 & 0.27 & 0.13 & 0.17 & 0.22 & 0.12 & 0.28 & 0.16 & 0.25 & 0.38 & 1 & & \\
\hline LV & 0.10 & 0.14 & 0.13 & -0.14 & 0.03 & -0.06 & 0.09 & 0.19 & 0.15 & -0.03 & 0.14 & 0.08 & 0.15 & 0.30 & 0.20 & 0.09 & 0.10 & 1 & \\
\hline LT & 0.24 & 0.14 & 0.22 & 0.14 & 0.24 & 0.14 & 0.05 & 0.26 & 0.34 & 0.16 & 0.26 & 0.27 & 0.06 & 0.30 & 0.31 & 0.31 & 0.26 & 0.57 & 1 \\
\hline EA & 0.12 & 0.33 & 0.74 & 0.31 & 0.53 & 0.58 & 0.23 & 0.51 & 0.24 & 0.63 & 0.25 & 0.25 & 0.37 & 0.08 & 0.12 & 0.23 & 0.25 & -0.07 & 0.01 \\
\hline
\end{tabular}

Note: Data are available only from 2001Q2 to $2011 Q 1$ for Greece, from 2001Q2 to 2013 Q2 for Malta and from 1999Q3 to 2013Q3 for Ireland and Portugal; statistical significance of correlation coefficients is presented in Appendix 3 are introduce (due to lack of space).

Source: Eurostat (2014), author's calculations

The similarity of supply and demand shocks with the Euro Area ${ }^{7}$ is following: the highest similarity with the Euro Area has Germany (correlation coefficient 0.74 ). High values have also the Netherlands (0.63) Finland (0.53), France (0.58), Italy (0.51) with the Euro Area (so the states of core of the Euro Area). On the contrary the negative correlation coefficient has Latvia (-0.07) with the Euro Area. The lowest value have also Lithuania $^{8}(0.01)$ or Cyprus (0.08). There are the states which entered later to the Euro Area.

According to the results in the Table 1, we can see high similarity between Finland and Belgium (correlation coefficient 0.51), Germany and Finland (0.53), Germany and France (0.52), Germany and the Netherlands (0.56). The correlation coefficient of the

\footnotetext{
${ }^{7}$ We must take into account in interpretation of results between the Euro Area and the states of the Euro Area that all states are part of the Euro Area. Especially for largest economies the results can be biased.

${ }^{8}$ It is necessary to mention that Latvia and Lithuania were not the member countries of the Euro Area during the analysed period.
} 
other countries of core of the Euro Area is the lowest in the case of Austria (0.15) in relation with Germany (as economically the strongest country of the Euro area). Correlation of the periphery states (but original states of the Euro Area) is the highest in the case of Portugal (0.43) in relation with Germany. In opposite, the lowest in the case of Greece (0.10). Correlations between Germany and the states which entered later to the Euro Area are following: the highest correlation has Estonia (0.35), Slovakia (0.27) and Slovenia (0.26). The lowest values have Latvia (0.13) and Cyprus (0.14).

We can conclude that the highest values of similarity of demand shocks (and the highest similarity of demand shocks) have the states so called core of the Euro Area (especially Germany, France or Finland) and the lowest values (and the smallest similarity of demand shocks) have the states which entered to the Euro Area later, especially Malta, Cyprus or Latvia. Conversely, there are states of the periphery (e.g. Estonia) with higher correlations than the states of the core (e.g. Austria).

In the next Table 2, there are the results for similarity of supply shocks in the Euro Area.

Table 2 Similarity of supply shocks in the Euro Area

\begin{tabular}{|c|c|c|c|c|c|c|c|c|c|c|c|c|c|c|c|c|c|c|c|c|}
\hline & AT & $\mathrm{BE}$ & $\mathrm{DE}$ & ES & FI & FR & IE & IT & LU & NL & PT & EL & SI & CY & MT & SK & $\mathrm{EE}$ & LV & LT & $\overline{\text { EA }}$ \\
\hline AT & 1 & & & & & & & & & & & & & & & & & & & \\
\hline $\mathrm{BE}$ & 0.70 & 1 & & & & & & & & & & & & & & & & & & \\
\hline $\mathrm{DE}$ & 0.41 & 0.41 & 1 & & & & & & & & & & & & & & & & & \\
\hline ES & 0.52 & 0.58 & 0.55 & 1 & & & & & & & & & & & & & & & & \\
\hline FI & 0.27 & 0.55 & 0.51 & 0.51 & 1 & & & & & & & & & & & & & & & \\
\hline FR & 0.73 & 0.81 & 0.48 & 0.69 & 0.43 & 1 & & & & & & & & & & & & & & \\
\hline IE & 0.48 & 0.59 & 0.49 & 0.62 & 0.53 & 0.68 & 1 & & & & & & & & & & & & & \\
\hline IT & 0.47 & 0.58 & 0.50 & 0.64 & 0.44 & 0.60 & 0.52 & 1 & & & & & & & & & & & & \\
\hline LU & 0.60 & 0.58 & 0.70 & 0.66 & 0.51 & 0.68 & 0.67 & 0.45 & 1 & & & & & & & & & & & \\
\hline NL & 0.17 & 0.19 & 0.30 & 0.28 & 0.20 & 0.09 & 0.13 & 0.11 & 0.17 & 1 & & & & & & & & & & \\
\hline PT & 0.41 & 0.45 & 0.37 & 0.49 & 0.38 & 0.42 & 0.54 & 0.49 & 0.54 & 0.35 & 1 & & & & & & & & & \\
\hline EL & 0.63 & 0.58 & 0.48 & 0.43 & 0.25 & 0.65 & 0.51 & 0.40 & 0.57 & 0.06 & 0.18 & 1 & & & & & & & & \\
\hline SI & 0.37 & 0.39 & 0.51 & 0.50 & 0.40 & 0.47 & 0.60 & 0.46 & 0.62 & 0.19 & 0.41 & 0.51 & 1 & & & & & & & \\
\hline $\mathrm{CY}$ & 0.30 & 0.31 & 0.42 & 0.43 & 0.27 & 0.50 & 0.32 & 0.44 & 0.46 & -0.05 & 0.23 & 0.52 & 0.26 & 1 & & & & & & \\
\hline MT & 0.08 & 0.03 & -0.05 & -0.08 & 0.13 & 0.02 & -0.21 & 0.06 & -0.09 & -0.20 & -0.06 & 0.04 & -0.17 & 0.15 & 1 & & & & & \\
\hline SK & 0.19 & 0.13 & 0.20 & 0.19 & -0.02 & 0.23 & 0.14 & 0.29 & 0.09 & 0.06 & 0.00 & 0.19 & 0.29 & 0.38 & 0.15 & 1 & & & & \\
\hline $\mathrm{EE}$ & 0.42 & 0.50 & 0.45 & 0.44 & 0.25 & 0.53 & 0.46 & 0.34 & 0.44 & 0.14 & 0.39 & 0.42 & 0.22 & 0.20 & 0.09 & -0.01 & 1 & & & \\
\hline LV & 0.29 & 0.27 & 0.28 & 0.003 & 0.18 & 0.21 & 0.25 & 0.17 & 0.18 & -0.02 & 0.11 & 0.34 & 0.28 & 0.08 & 0.17 & 0.22 & 0.14 & 1 & & \\
\hline LT & 0.17 & 0.26 & 0.38 & 0.21 & 0.45 & 0.19 & 0.28 & 0.35 & 0.27 & 0.03 & 0.18 & 0.21 & 0.38 & 0.17 & 0.08 & 0.14 & 0.14 & 0.62 & 1 & \\
\hline EA & 0.56 & 0.67 & 0.80 & 0.67 & 0.59 & 0.60 & 0.68 & 0.59 & 0.89 & 0.29 & 0.52 & 0.56 & 0.62 & 0.41 & -0.11 & 0.12 & 0.53 & 0.20 & 0.28 & 1 \\
\hline
\end{tabular}

Note: Data are available only from 2001Q2 to 2011Q1 for Greece, from 2001Q2 to 2013 Q2 for Malta and from 1999Q3 to 2013Q3 for Ireland and Portugal; statistical significance of correlation coefficients are introduced in Appendix 3 (due to lack of space).

Source: Eurostat (2014), author's calculations

In the Table 2, we can see a higher correlation coefficient than in the case similarity of supply shocks (compared to demand shocks). With the exception of Latvia, Lithuania, Malta, the Netherlands and Slovakia, all countries in the Euro Area have correlation coefficients 0.5 and higher. The highest values were recorded for Luxemburg (0.89) and Germany (0.80). On the other end of the scale, the lowest (negative) correlation coefficient $(-0.11)$ in the Euro Area was found in Malta. Slovakia is another country with a low correlation coefficient $(0.12)$. 
Germany achieves the highest correlation coefficients (after Luxembourg). High correlation coefficients have been found also in the case of Belgium, Ireland, Luxemburg, Spain or France (mostly the countries of the core, but with some exceptions). From the core countries, the Netherlands has the lowest correlation in relation with Germany. The periphery states (but original states of the Euro Area) also have recorded a high correlation (e.g. Spain). Correlations between Germany and the states which entered the Euro Area later are varied: the highest values are for Slovenia (0.51), Estonia (0.45) or Cyprus (0.42). Malta stands on the other end, having the lowest values (almost zero, -0.05).

Again, we can claim that the highest correlation coefficients (and the highest similarity of supply shocks) was found in the states of the so-called core of the Euro Area (with some exceptions - e.g. the Netherlands).

\section{NAFTA}

There are the results of similarity of supply and demand shocks (correlation coefficients) in the countries of NAFTA in the following Table 3. The left side of the Table 3 deals with the results of similarity of supply shocks and the right side deals with the results of similarity of demand shocks.

Table 3 Similarity of supply and demand shocks in NAFTA

\begin{tabular}{l|ccc|c|ccc}
\hline \multicolumn{3}{|c|}{ Supply shocks } & \multicolumn{4}{c}{ Demand shocks } \\
\hline & CAN & MEX & USA & & CAN & MEX & USA \\
\hline CAN & 1 & & & CAN & 1 & & \\
MEX & 0.05 & 1 & & MEX & $0.55^{* * *}$ & 1 & \\
USA & $0.73^{* * *}$ & -0.02 & 1 & USA & $0.41^{* * *}$ & $0.28^{* * *}$ & 1 \\
\hline$* * * 1 \%$ significance level, ** 5\% significance level, * $10 \%$ significance level \\
Source: OECD (2014), author's calculations
\end{tabular}

In the case of supply shocks, Canada achieves high value of the correlation coefficient with the United States (0.73). The results of other coefficients are low in the case of supply shocks. The correlation coefficient is almost zero (0.05) between Canada and Mexico, and it is also almost zero (-0.02) between Mexico and the United States. We can conclude that similarities of supply shocks among states of NAFTA are ambiguous. Correlation is high between Canada and the United States, but supply shocks between Canada and Mexico and between the United States and Mexico are uncorrelated. This can be caused by dependence of the Mexican economy on oil industry. The fluctuation of oil prices significantly influences the supply side of economy in Mexico.

The results of similarity of demand shocks are quite different. The best correlation coefficient is between Canada and Mexico (0.55). The second best value is between Canada and the United States (0.41). The worst value is between Mexico and the United States (0.28). But the results of similarity of demand shocks in the NAFTA states are relatively high. 


\section{MERCOSUR}

Table 4 shows the results of similarity of supply and demands shocks in the countries of MERCOSUR. On the left side of the Table 4, there are results for similarity of supply shocks, the right side presents results for similarity of demand shocks.

Table 4 Similarity of supply and demand shocks in MERCOSUR

\begin{tabular}{|c|c|c|c|c|c|c|c|c|c|c|c|}
\hline \multicolumn{6}{|c|}{ Supply shocks } & \multicolumn{6}{|c|}{ Demand shocks } \\
\hline & ARG & BRA & PAR & URY & VEN & & ARG & BRA & PAR & URY & VEN \\
\hline ARG & 1 & & & & & ARG & 1 & & & & \\
\hline BRA & -0.05 & 1 & & & & BRA & $0.29^{* *}$ & 1 & & & \\
\hline PAR & 0.10 & $0.31^{* *}$ & 1 & & & PAR & $0.26^{*}$ & $0.28^{* *}$ & 1 & & \\
\hline URY & $-0.35^{*}$ & -0.01 & -0.19 & 1 & & URY & $0.43^{* *}$ & $0.32^{*}$ & $0.39^{* *}$ & 1 & \\
\hline VEN & $0.23^{*}$ & 0.05 & 0.07 & -0.09 & 1 & VEN & 0.11 & 0.12 & -0.01 & 0.20 & 1 \\
\hline
\end{tabular}

The similarity of supply shocks is low in the case of the MERCOSUR states, the exceptions being correlation coefficients between Paraguay and Brasil (0.31), and between Venezuela and Argentina (0.23). The correlation coefficient of Argentina with Brasil is close to zero (-0.05), supply shocks are uncorrelated between Argentina and Paraguay (0.10), and with Uruguay, Argentina achieves negative correlation coefficients (-0.35). Uruguay has negative correlation coefficients in all cases (but with Brasil is the correlation coefficient almost zero). It can also be caused by shorter time series. Venezuela has low values (except for with Argentina), too. The reason can be the fact that Venezuelan economy, too, is dependent on oil industry. Prices of oil influence occurrence of supply shocks in Venezuela.

Similarity of demand shocks is higher than in the case of supply shocks. Argentina achieves the highest similarity of supply shocks with Uruguay (0.43), with Brasil (0.29), with Paraguay (0.26) and with Venezuela 0.11 (the lowest value). Venezuela is the country that has the lowest value with all states, with Paraguay almost zero $(-0.01)$. On the other hand, it is relatively high with Uruguay $(0.20)$. Otherwise, the correlation coefficients of demands shocks are from 0.26 to 0.43 . Overall, the similarity of supply shocks is lower in the case of MERCOSUR state.

\section{Comparison}

The best values (the highest correlation coefficients) have been found for the Euro Area countries. From these countries, it is true especially for the countries of so-called core of the Euro Area - Germany, France, Belgium, Luxemburg or Finland. The countries of the so-called periphery of the Euro Area and the countries which entered the Euro Area later have lower coefficients correlation generally.

NAFTA countries have the second best values, especially as far as similarity of demand shocks is concerned. The similarity of supply shocks is lower due to Mexico and its 
dependence on oil industry. But NAFTA countries achieve high correlation coefficients in comparison with MERCOSUR or with some of the Euro Area countries (especially with the periphery states). It is in accordance with Chriszt (2000) who claims that NAFTA is ready for creating a monetary union according to the OCA theory and that Canada is more prepared than Mexico.

MERCOSUR achieves the lowest correlation coefficients. Although MERCOSUR is a customs union, it has lower similarities of supply and demand shocks than NAFTA which is a free trade area (i.e. a lower degree of economic integration). It is the similarity of supply shocks in particular that is very low. We can say that the MERCOSUR countries are not ready for a monetary union. Numa (2011) also claims that MERCOSUR is not ready for creation of a common currency.

\section{Conclusions}

This paper deals with similarity of supply and demand shocks in the Euro Area, NAFTA and MERCOSUR. The aim of this paper was to assess the similarity of demand and supply shocks in the countries of NAFTA and MERCOSUR, and to compare it with the countries of the Euro Area. We use a structural vector autoregression model for this aim. The model is based on Blanchard and Quah (1989) and Bayoumi and Eichengreen (1993).

Table 1 and Table 2 shows us that Germany achieves very good results. Germany is a substantial part of the Euro Area so it is obvious that the correlation coefficients are high here. But Germany has also high values with some other countries, too; especially with the states of the core of the Euro Area - France, Finland or Luxemburg. Quite surprisingly, the Netherlands has poor values in the case of supply shocks. It can be caused by a number of firms which have a residence in the Netherlands. So this very specific situation of the Dutch economy can cause the diverging results. Also Malta, Latvia or Slovakia have smaller similarities of supply and demand shocks. These states entered the Euro Area later. We confirmed the existence of core and periphery in the Euro Area with some exceptions (e. g. the Netherlands in the case of supply shocks). If we compare supply and demand shocks, we find more similarities in the case of supply shocks (likewise e. g. Hušek and Fománek, 2011). But we assume that similarity of demand shocks is more important for successful single monetary policy in the Euro Area because the European Central Bank, i.e. the central bank of the Euro Area, can better influence a demand side of economy than a supply side.

In NAFTA, similarity of supply shocks is high between the United States and Canada. Both of these states have scored low values of correlation with Mexico because Mexico is substantially dependent on oil industry. Similarity of supply shocks is the highest between Canada and Mexico. Similarity of demand shocks is high between the United States and Mexico and between the United States and Canada, too.

MERCOSUR is characteristic by low similarity of supply shocks. The correlation coefficients are negative or close to zero in most cases. The results for similarity of demand shocks are higher, except for Venezuela. Nevertheless, the similarity of demand shocks is relatively low. 
If we compare the Euro Area, NAFTA and MERCOSUR, we the best values can be seen in the states of the so-called core of the Euro Area. NAFTA achieves high correlation coefficients (except Mexico in supply shocks). Low results are among the states of the Euro Area of the so-called periphery. MERCOSUR has also quite low correlations. It can be thus concluded that according to a similarity of supply and demand shocks, which is one of the criterion of the optimum currency area theory, the Euro Area (with some exceptions) and NAFTA (with some exceptions, too) are more ready for a monetary integration than MERCOSUR.

\section{References}

BAYOUMI, T., EICHENGREEN, B. (1993). Shocking Aspects of European Monetary Integration. In Adjustment and Growth in the European Monetary Union. Cambridge: Cambridge University Press, pp. 193-230. ISBN 978-05214400196.

BLANCHARD, O. J., QUAH, D. (1989). The Dynamics Effects of Aggregate Demand and Supply Disturbances. American Economic Review.79 (4), pp. 655 - 673. ISSN 0002-8282.

CHRISZT, M. (2000).Perspective in a Potential North American Monetary Union. Federal Reserve Bank of Atlanta. Economic Review. 2000 (4), pp. 29-38. ISSN 0732-1813.

COHEN, B. J. (2004). North American Monetary Union: A United States Perspective. Orfalea Centre for Global \& International Studies. UC Santa Barbara: Global and International Studies.

DĚDEK, O. (2008). Historie evropské měnové integrace. Od národních měn k euru. Praha: C. H. Beck. ISBN 978-80-7400-076-8.

Economic Commission for Latin America and the Caribbean. (2014). CEPALSTAT. Database and Statistical Publications. Retrieved August 20, 2014, from http://estadisticas.cepal.org/cepalstat/WEB_CEPALSTAT/estadisticasIndicadores.asp?i dioma $=$ i.

Eurostat. (2014). Statistics Database. Retrieved July 15, 2014, from http://epp.eurostat.ec.europa.eu/portal/page/portal/statistics/search_database.

FIDRMUC, J., KORHONEN, I. (2003). Similarity of Supply and Demand Shocks Between the Euro Area and the CEECs. Economic Systems. 27 (3), pp. 313-334. ISSN 0939-3625.

FIDRMUC, J., KORHONEN, I. (2006). Meta-Analysis of the Business Cycle Correlation between the Euro Area and the CEECs. CESifo Working Paper No. 1693.

FRANKEL, J. A., ROSE, A. K. (1996). The Endogenity of the Optimum Currency Area Criteria. NBER Working Papers 5700. Cambridge (MA): National Bureau of Economic Research.

FRENKEL, M., NICKEL, C. (2002). How Symmetric Are the Shocks and the Shock Adjustment Dynamics Between the Euro Area and Central and Eastern European Countries? IMF Working Paper 02/222. 
GRAUWE, P. de (2014). Economics of Monetary Union. Oxford: Oxford University Press. ISBN 978-0-19-968444-1.

GRIGOLI, F. (2012). The Impact of Trade Integration on Business Cycle Synchronization for Mercosur Countries. European Journal of Comparative Economics. 9 (1), pp. 103-131, pp. 103-131. ISSN 1722-4667.

HORVATH, J., RÁTFAI, A. (2004). Supply and Demand Shocks in Accession Countries to the Economic and Monetary Union. Journal of Comparative Economics. 32 (2), pp. 202-211. ISSN 0147-5967.

HUŠEK, R. (2009). Aplikovaná ekonometrie: teorie a praxe. Praha: Oeconomica. ISBN 978-80-345-1623-3.

HUŠEK, R., FORMÁNEK, T. (2011). Srovnání konvergence ekonomik ČR a vybraných zemí eurozóny na základě analýzy funkcí odezvy a nabídkových či poptávkových šoků. Politická ekonomie. 2011 (3), pp. 291-309. ISSN 0032-3233.

KENEN, Peter B., (1969). The Theory of Optimum Currency Areas. In Monetary Problems of the International Economy. Chicago University Press, pp. 41-60.

KRČÍLKOVÁ, M., ZÁPAL, J. (2012). Mundell in 3D, Synchronization of Supply and Demand Shocks among Sectors no Countries, with Application to CEEC. Empirica. 39 (3), pp. 407-434. ISSN 1573-6911.

KRUGMAN, P. (1993). Lesson of Massachusetts for EMU. In Adjustment and Growth in the European Monetary Union. Cambridge: Cambridge University Press, pp. 241-261 ISBN 978-0521440196.

KUČEROVÁ, Z. (2005). Teorie optimální měnové oblasti a možnosti její aplikace na země střední a východní Evropy. Studie Národohospodářského ústavu Josefa Hlávky 3/2005. ISBN 80-86729-18-4.

LACINA, L. (2007). Měnová integrace: náklady a přinosy v měnové unii. Praha: C. H. Beck. ISBN 978-80-7179-560-5.

LÜTKEPOHL, H., KRÄTZIG, M. (eds.). (2004). Applied Time Series Econometrics. Cambridge: Cambridge University Press. ISBN 978-0-521-54787-3.

McKINNON, R. I. (1963). Optimum Currency Areas. American Economic Review. 53 (4), pp. 717-725. ISSN 0002-8282.

MONGELLI, F. P. (2002). "New“ Views on the Optimum Currency Area Theory: What is EMU Telling us? European Central Bank Working Paper, no. 138, April 2002.

MUNDELL, R. A. (1961). Theory of Optimum Currency Areas. American Economic Review.51 (4), pp. 657-665. ISSN 0002-8282.

NUMA, M. (2011).The Feasibility of a Monetary Union in MERCOSUR. Michigan Journal of Business.4 (2), pp. 11-59. ISSN 1941-5745.

Organisation for Economic Co-Operation and Development. (2014). OECD StatExtracts. Retrieved July 22, 2014, from http://stats.oecd.org/. 


\section{Appendix 1}

The Estimation of the Number of VAR Lags

\begin{tabular}{|c|c|c|c|c|c|}
\hline Countries & Sequential LR & $A I C$ & $S C$ & $H Q$ & Chosen lag \\
\hline AT & 4 & 4 & 4 & 4 & 4 \\
\hline $\mathrm{BE}$ & 4 & 4 & 0 & 4 & 4 \\
\hline $\mathrm{CY}$ & 4 & 4 & 1 & 4 & 4 \\
\hline EA & 4 & 1 & 1 & 1 & 1 \\
\hline $\mathrm{EE}$ & 4 & 4 & 1 & 4 & 4 \\
\hline FI & 1 & 1 & 1 & 1 & 1 \\
\hline FR & 4 & 4 & 1 & 4 & 4 \\
\hline $\mathrm{DE}$ & 1 & 1 & 1 & 1 & 1 \\
\hline EL & 4 & 4 & 4 & 4 & 4 \\
\hline IE & 5 & 5 & 0 & 5 & 5 \\
\hline IT & 4 & 4 & 1 & 4 & 4 \\
\hline $\mathrm{LT}$ & 1 & 1 & 1 & 1 & 1 \\
\hline LV & 4 & 4 & 1 & 1 & 4 \\
\hline LU & 4 & 0 & 0 & 0 & 1 \\
\hline MT & 4 & 4 & 0 & 0 & 4 \\
\hline NL & 3 & 4 & 1 & 3 & 3 \\
\hline PT & 4 & 4 & 0 & 4 & 4 \\
\hline SI & 4 & 1 & 1 & 1 & 1 \\
\hline ES & 4 & 4 & 4 & 4 & 4 \\
\hline SK & 4 & 4 & 0 & 1 & 4 \\
\hline CAN & 4 & 4 & 1 & 1 & 4 \\
\hline MEX & 1 & 1 & 1 & 1 & 1 \\
\hline USA & 4 & 4 & 1 & 4 & 4 \\
\hline ARG & 2 & 2 & 1 & 2 & 2 \\
\hline BRA & 4 & 4 & 1 & 2 & 4 \\
\hline PAR & 0 & 0 & 0 & 0 & 4 \\
\hline URY & 3 & 0 & 0 & 0 & 3 \\
\hline VEN & 1 & 1 & 1 & 1 & 1 \\
\hline
\end{tabular}

Note: LR: sequential modified LR test statistic (each test at 5\% level, AIC: Akaike information criterion, SC: Schwarz information criterion, HQ: Hannan-Quinn information criterion Source: Eviews 7, author's calculations 


\section{Appendix 2}

\section{Accumulated Impulse-Response Functions of Output of the researched states}

The Euro Area states

\section{Austria}

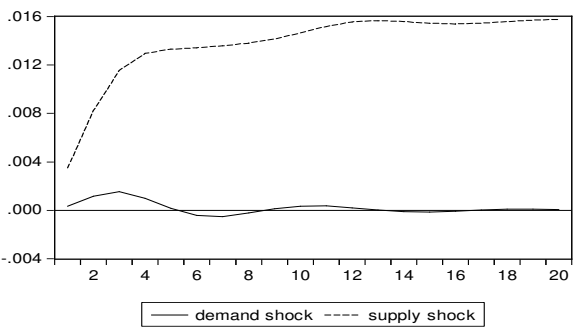

\section{Cyprus}

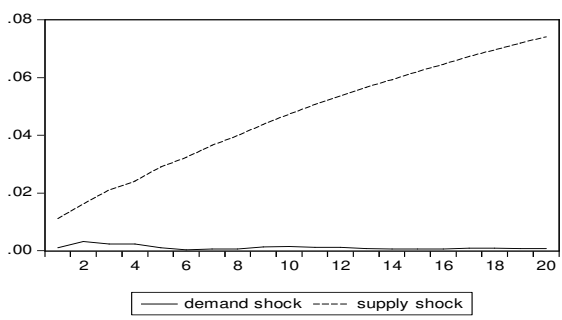

\section{Estonia}

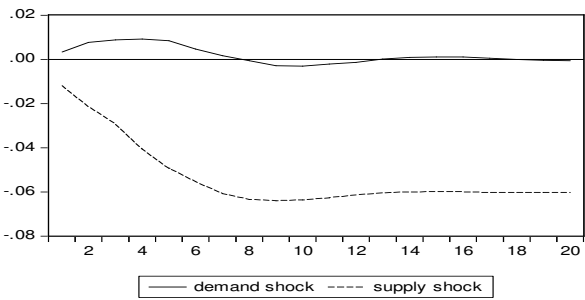

\section{France}

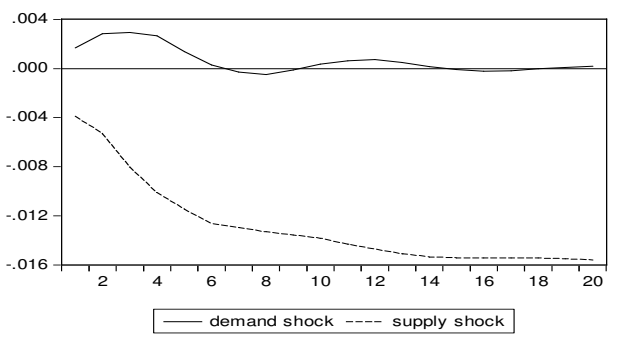

\section{Belgium}

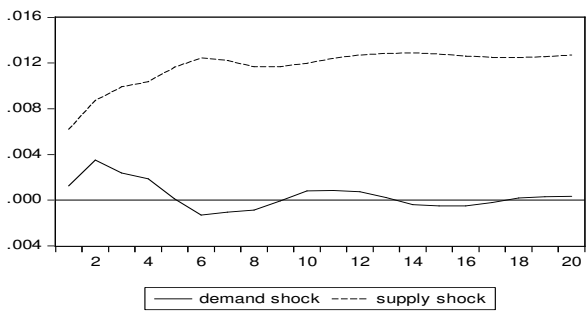

the Euro Area

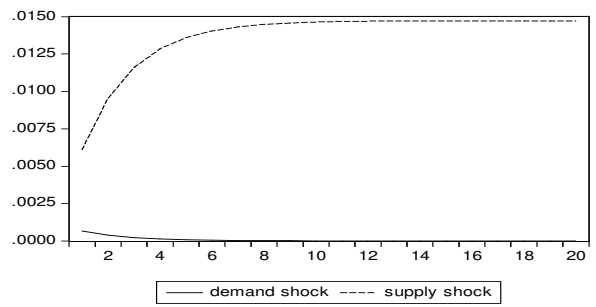

Finland

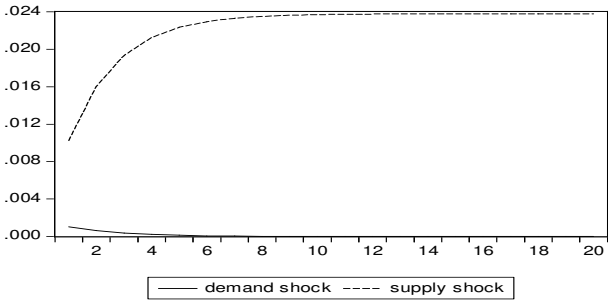

Germany

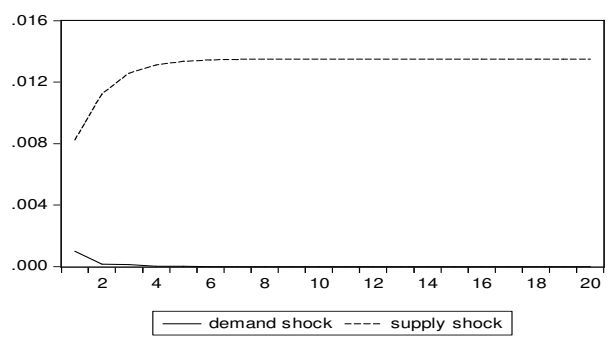




\section{Greece}

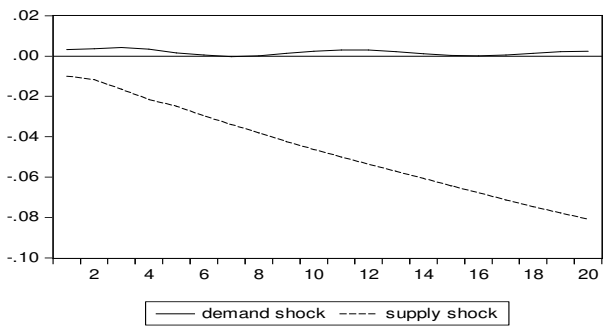

\section{Italy}

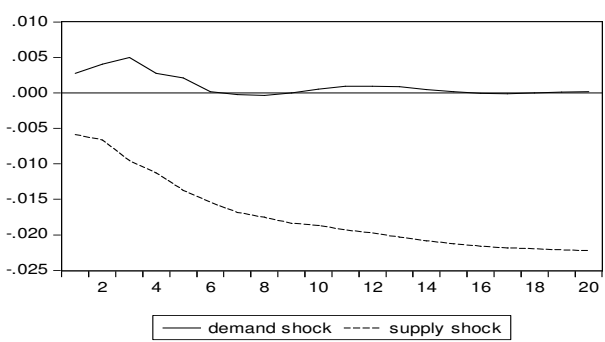

\section{Latvia}

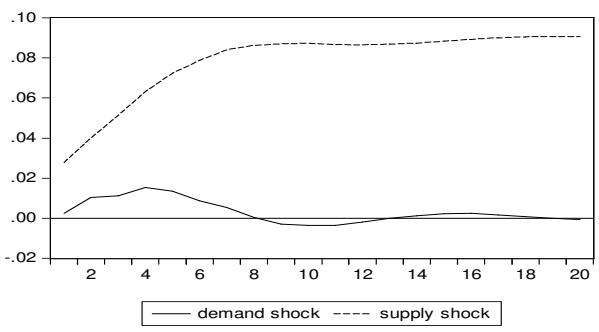

\section{Malta}

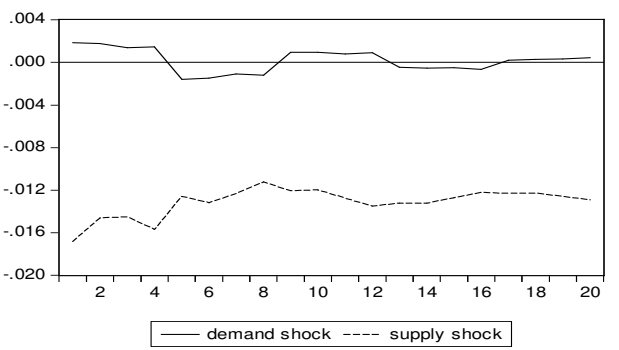

\section{Ireland}

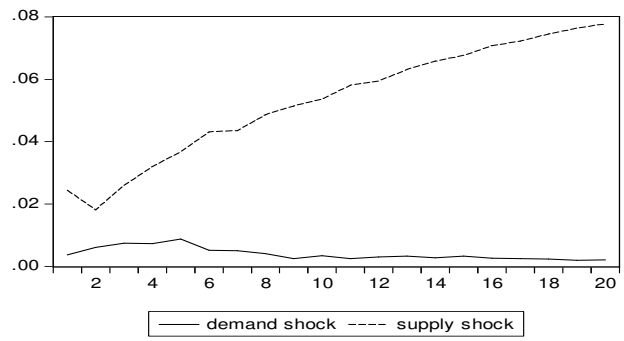

\section{Lithuania}

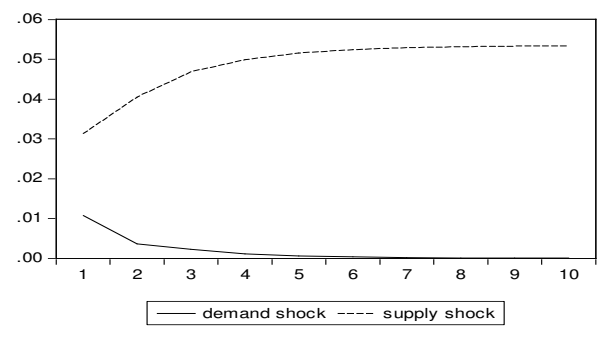

\section{Luxemburg}

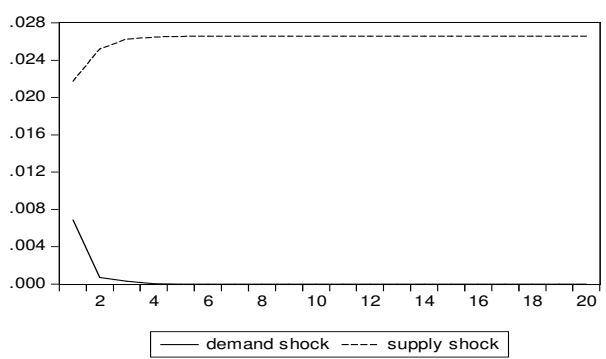

the Netherlands

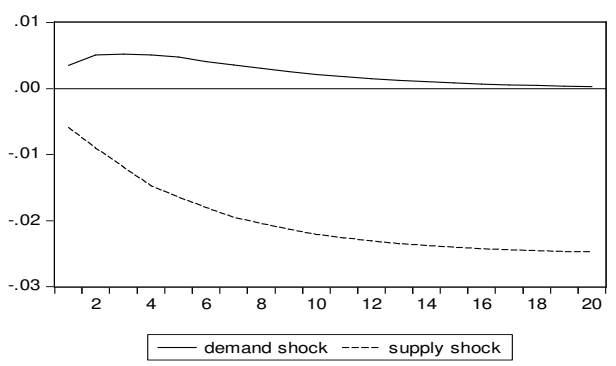




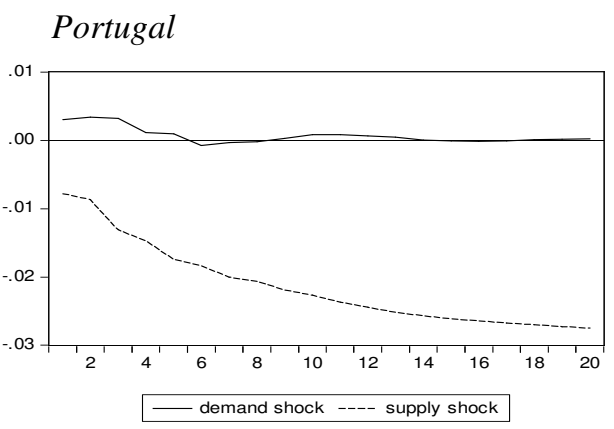

\section{Spain}

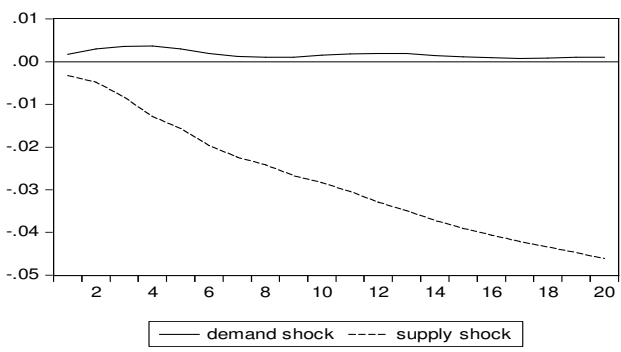

NAFTA

\section{Canada}

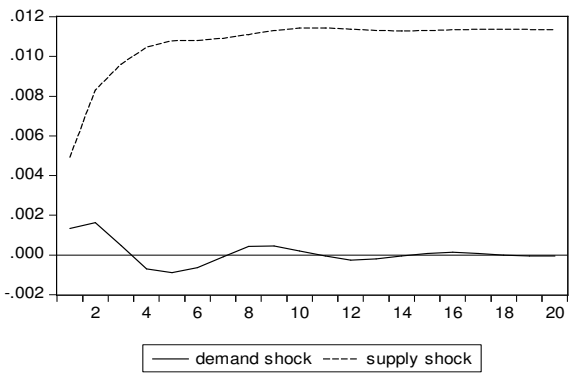

the United States

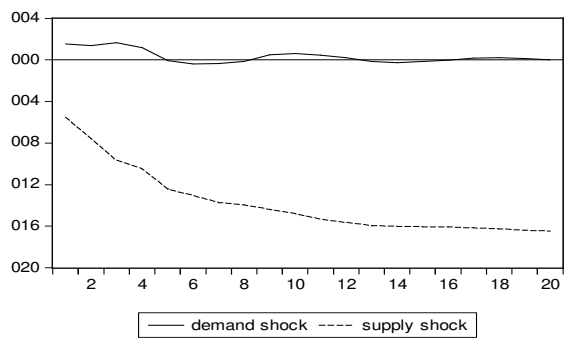

\section{Slovenia}

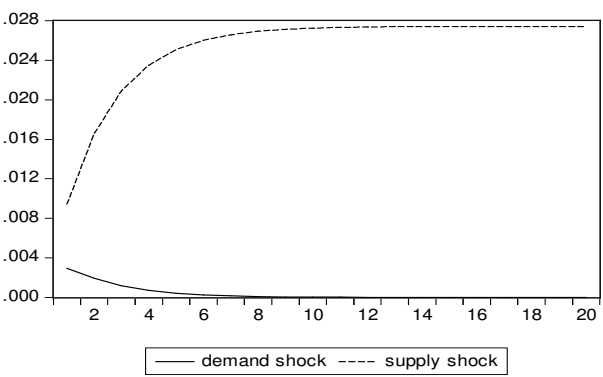

\section{Slovakia}

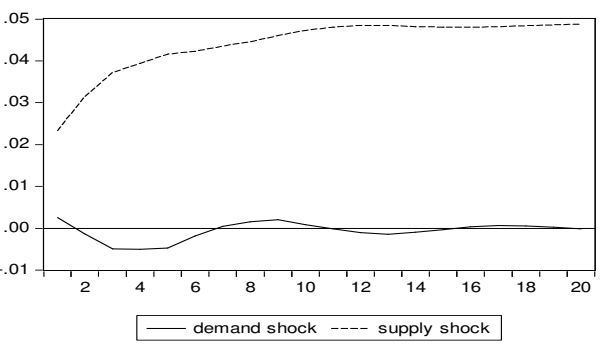

Mexico

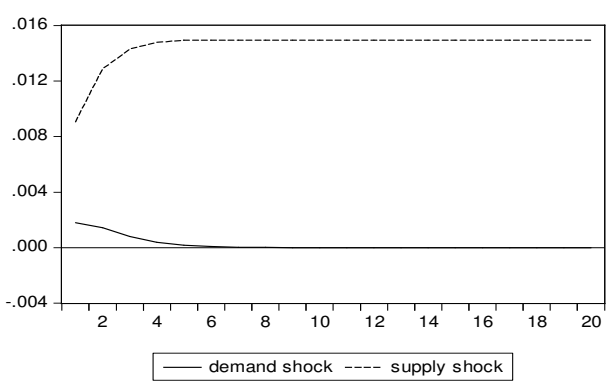




\section{MERCOSUR}

Argentina

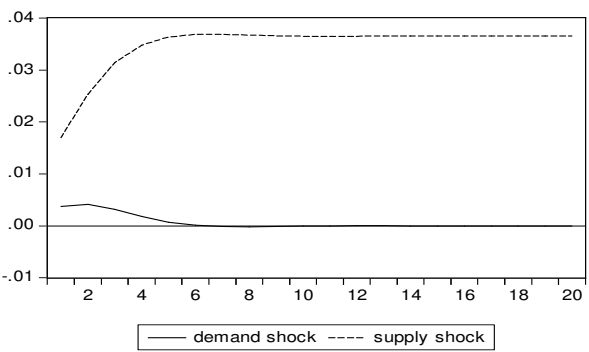

\section{Paraguay}

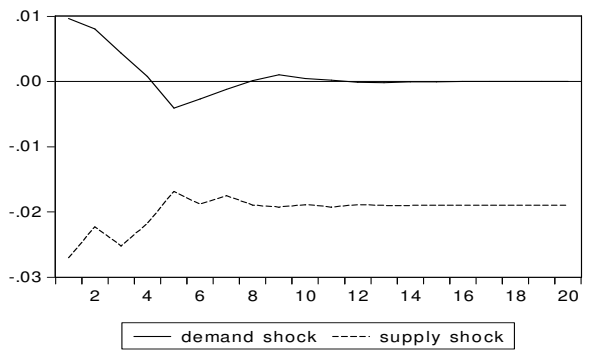

Venezuela

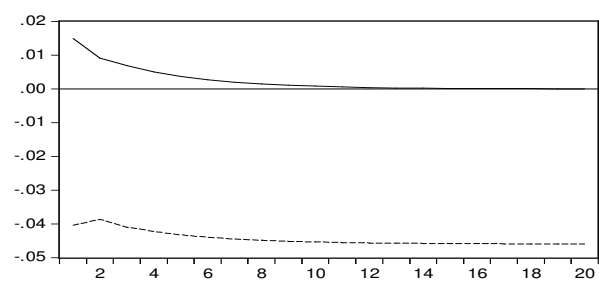

- demand shock ---- supply shock

\section{Brazil}

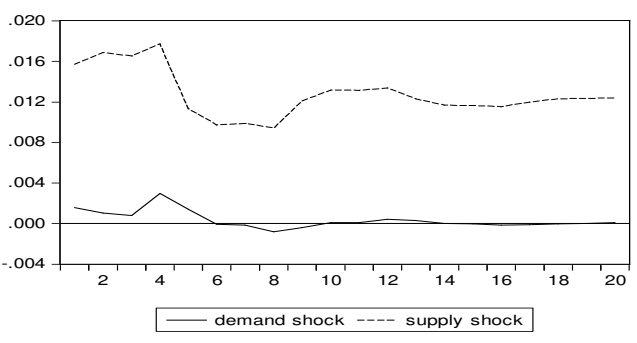

Uruguay

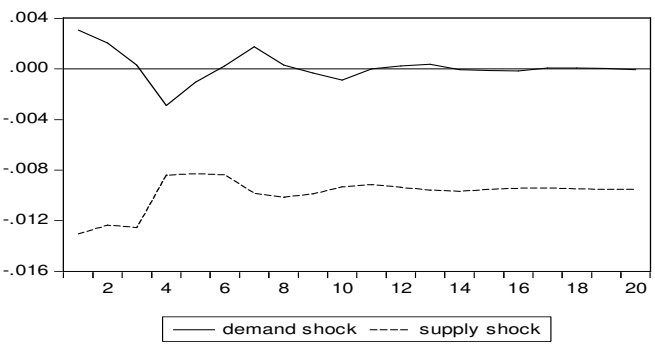




\section{Appendix 3}

Statistical significance of correlation coefficients of demand shocks in the countries of the Euro Area

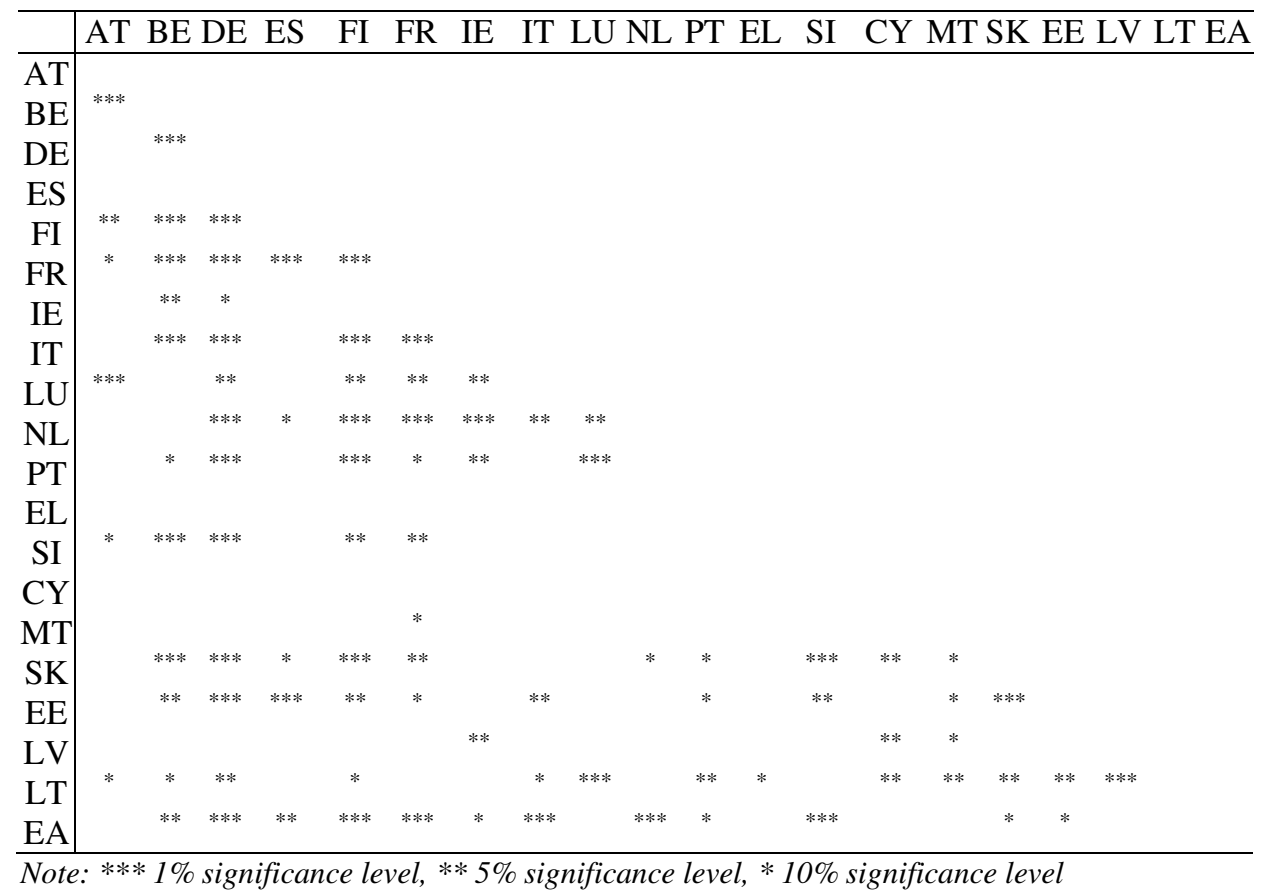


Statistical significance of correlation coefficients of supply shocks in the countries of the Euro Area

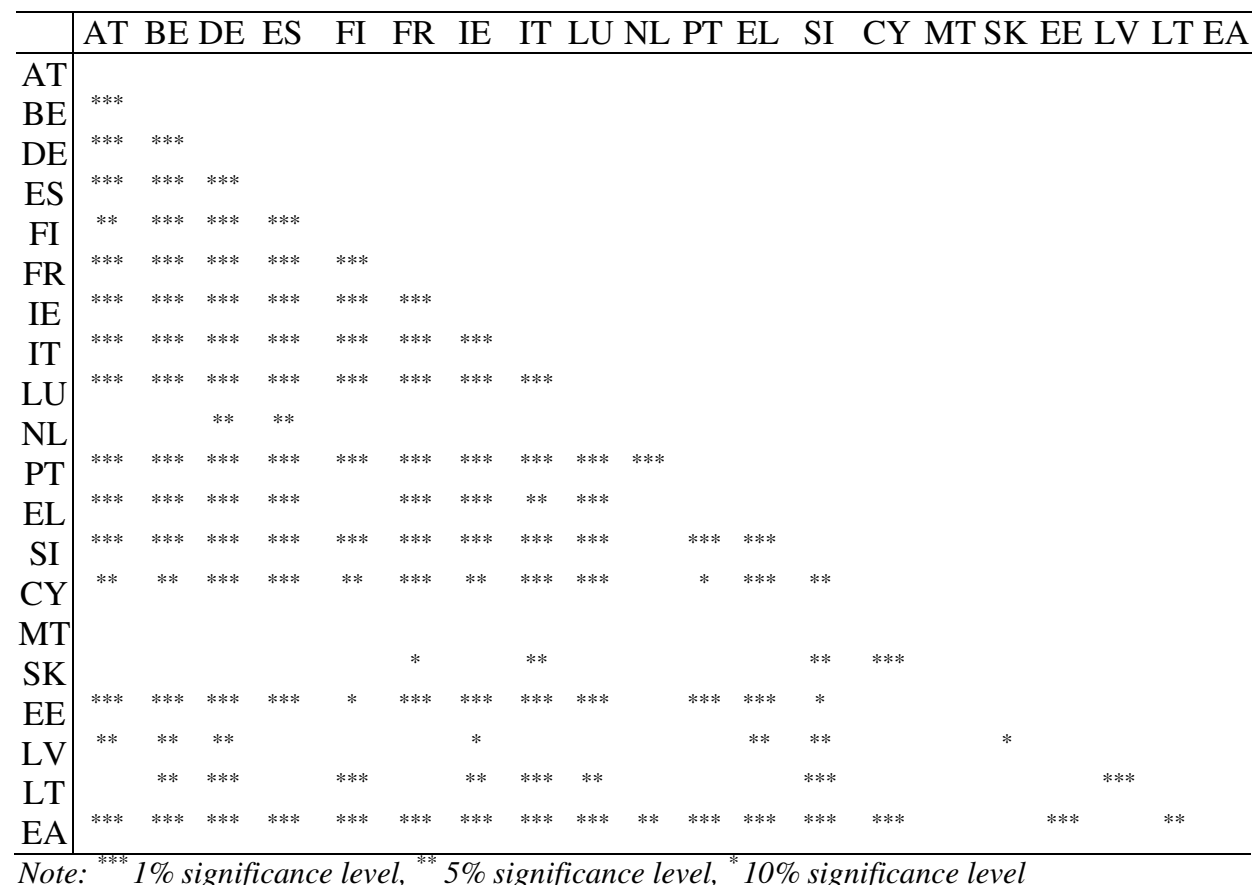

